Review

\title{
Implications of Endogenous Retroelements in the Etiopathogenesis of Systemic Lupus Erythematosus
}

\author{
Kennedy C. Ukadike (D) and Tomas Mustelin *(D) \\ Division of Rheumatology, Department of Medicine, University of Washington School of Medicine, \\ 750 Republican Street, Seattle, WA 98109, USA; kukadike@uw.edu \\ * Correspondence: tomas2@uw.edu; Tel.: +1-(206)-313-6130
}

check for

updates

Citation: Ukadike, K.C.; Mustelin, T. Implications of Endogenous Retroelements in the Etiopathogenesis of Systemic Lupus Erythematosus. J. Clin. Med. 2021, 10, 856. https:// doi.org/10.3390/jcm10040856

Academic Editor: Philippe Guilpain Received: 31 December 2020

Accepted: 13 February 2021

Published: 19 February 2021

Publisher's Note: MDPI stays neutral with regard to jurisdictional claims in published maps and institutional affiliations.

Copyright: (C) 2021 by the authors Licensee MDPI, Basel, Switzerland. This article is an open access article distributed under the terms and conditions of the Creative Commons Attribution (CC BY) license (https:// creativecommons.org/licenses/by/ $4.0 /)$.

\begin{abstract}
Systemic lupus erythematosus (SLE) is a heterogeneous autoimmune disease. While its etiology remains elusive, current understanding suggests a multifactorial process with contributions by genetic, immunologic, hormonal, and environmental factors. A hypothesis that combines several of these factors proposes that genomic elements, the L1 retrotransposons, are instrumental in SLE pathogenesis. L1 retroelements are transcriptionally activated in SLE and produce two proteins, ORF1p and ORF2p, which are immunogenic and can drive type I interferon (IFN) production by producing DNA species that activate cytosolic DNA sensors. In addition, these two proteins reside in RNA-rich macromolecular assemblies that also contain well-known SLE autoantigens like Ro60. We surmise that cells expressing L1 will exhibit all the hallmarks of cells infected by a virus, resulting in a cellular and humoral immune response similar to those in chronic viral infections. However, unlike exogenous viruses, L1 retroelements cannot be eliminated from the host genome. Hence, dysregulated L1 will cause a chronic, but perhaps episodic, challenge for the immune system. The clinical and immunological features of SLE can be at least partly explained by this model. Here we review the support for, and the gaps in, this hypothesis of SLE and its potential for new diagnostic, prognostic, and therapeutic options in SLE.
\end{abstract}

Keywords: systemic lupus erythematosus; retroelements; L1; LINE-1; reverse transcriptase; type I interferons; autoimmunity

\section{Introduction}

Systemic lupus erythematosus (SLE) is a varied and often debilitating autoimmune disease that affects at least 5 million people worldwide, and women more than men with a striking gender bias of 9:1. The precise etiology of SLE remains elusive despite many decades of research to better understand it. Current knowledge suggests a multifactorial etiology with contributions from genetic, immunologic, hormonal, and environmental factors [1,2]. Even at that, the exact extent to which each of these factors contribute to SLE pathogenesis is not known. While we focus here on a specific emerging mechanism that combines genomic/genetic and immunologic factors, with hormonal and environmental contributions, we wish to first place it in the context of the broader genetic associations of SLE.

Genome-wide association studies have identified many genes with polymorphisms and copy number variants that are associated with SLE [3-7]. The most significant associations are found in the major histocompatibility complex II (MHC II), which include alleles of $H L A-D R 2, H L A-D R 3$, and $H L A-D Q 2$ [8-10]. Deficiencies of the complement components C1q [11], C2, C4A, and C4B, which confer an even higher risk for SLE, are relatively rare [12]. Similarly, rare polymorphisms or mutations in DNases TREX1 [13] and DNASE1 [14] also confer significant risk of SLE. Deletion of trex1 in mice results in accumulation of single-stranded DNA derived from reverse transcription of retroelement RNA, elevated type I interferon production, and severe autoimmunity [15]. In humans, 
loss-of-function mutations in DNASE1L3 also result in a SLE-like disease [16]. This gene encodes for an active DNase that is secreted by innate immune cells to degrade chromatin released passively (apoptosis and necrosis) or actively (NETosis) from dying cells. Together, these genes imply a pathogenic role of cytosolic DNA originating from retroelements, and the importance of effective clearance of DNA in immune complexes and cellular debris.

In agreement with this notion, several genes with a role in IFN signaling, such as IRF5, IRAK1, STAT4, SPP1, TNFAIP3, and PTPN22, also have SLE-predisposing variants, which are associated with high levels of type I IFNs and increased expression of IFN-inducible genes [17-21]. Polymorphisms in genes involved upstream of IFNs, such as IFIH1 [22] and TLR7 [23], have also been documented. Other genes implicated in the adaptive immune system, including PTPN22, PDCD1 (encodes PD-1) [24], BANK-1 [25], BLK, LYN, and TNFRSF4 (OX40L), indicate that the threshold for activation of $B$ and $\mathrm{T}$ cells is important in SLE [26-29]. The MHC association also supports this notion. Unlike the rare complement deficiencies and DNase mutations, these gene polymorphisms individually confer a very modest risk (odds ratio $<2$ ) for SLE, suggesting that they are not directly causative, but in aggregate increase the susceptibility to SLE, presumably in combination with the absence of protective gene variants [30,31], genomic hypomethylation, altered epigenetic control, changes in microRNAs (miRNAs) [32-36], and the presence of environmental or endogenous triggers [34-36].

In accordance with the genetics of SLE summarized above, we focus in this review on an emerging concept that is well compatible with the genetic associations, namely the notion that endogenous virus-like sequences may play a part in the pathogenesis of SLE and other related diseases [37-40]. These genomic sequences are either remnants of exogenous retroviruses that infected our ancestors millions of years ago [40-42], or ancient descendants of retroviruses that retained the ability to embed and replicate within the germline genome to become extremely abundant throughout the human genome $[40,43]$. Although the vast majority of all these sequences are now inactive due to mutations and truncations, a number of them are still more or less intact and able to create extrachromosomal DNA, trigger type I IFNs, and provoke an antiviral type of immune response. The biology of these retroelements and the evidence for their involvement in SLE are discussed here.

\section{Transposable Elements in the Human Genome}

Colloquially known as "jumping genes" or "parasitic DNA" [44], transposable elements (or transposons) are genomic DNA sequences that have the ability to move within the genome, thereby altering its organization, incrementally increasing its size, and creating duplications and redundancy [45]. There are two broad classes of transposons: Class I transposons, also known as retrotransposons, and class II or DNA transposons [46]. The former propagate using a "copy-and-paste" mechanism that consists of a reverse transcriptase (RT) that uses its own RNA transcript as a template to generate a cDNA copy, which is inserted into the genome. The latter move by a "cut-and-paste" mechanism by their encoded transposase enzyme. To the best of our knowledge, only class I transposons have been implicated in the autoimmune disease and will be discussed further here.

To illustrate the sheer volume of retrotransposons in our genome, compared to all the exons of our 20,000 genes, which occupy approximately $1 \%$ of our 3-billion base-pair genome, the retroelements occupy close to $50 \%$ of it [44,47]. There are over 3 million retroelements in our genome [48]. They fall into three categories: the over 440,000 long terminal repeat (LTR) retrotransposons, also known as human endogenous retroviruses (HERVs), the 800,000 autonomous non-LTR retrotransposons termed long interspersed nuclear elements (LINEs), and the 1,500,000 copies of the short interspersed nuclear elements (SINEs), which are non-autonomous and include over 1 million Alu elements [49] (Figure 1). 


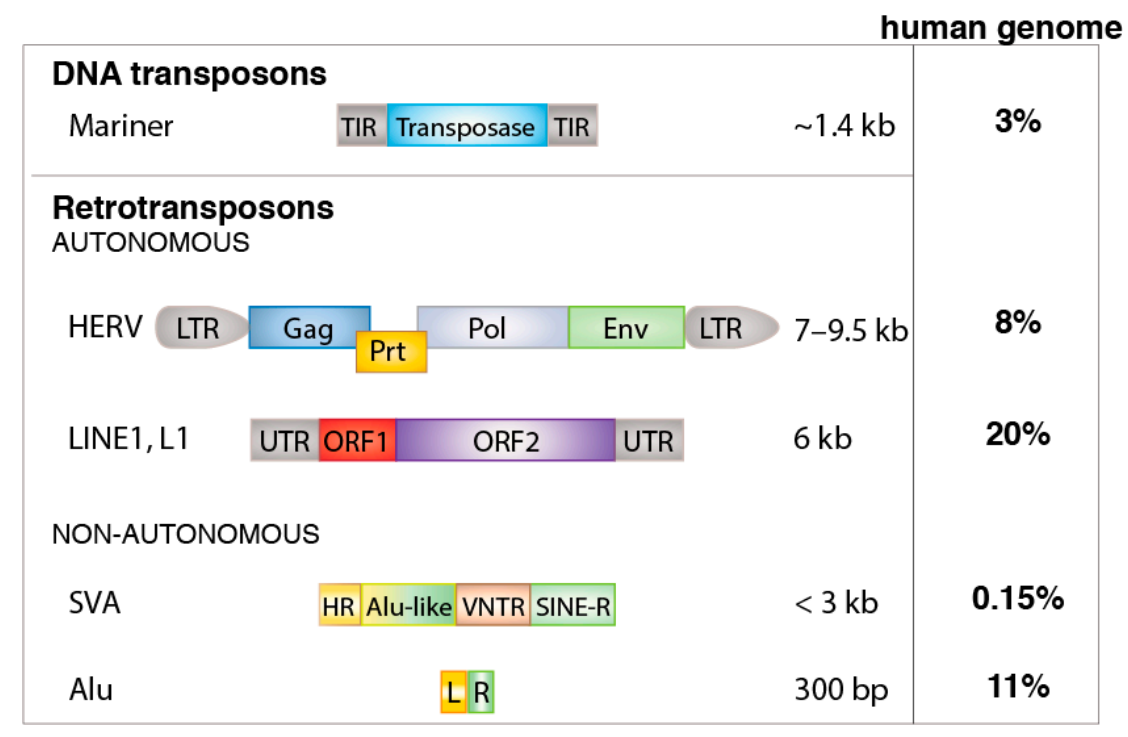

Figure 1. Classes and examples of transposable elements. Abbreviations: TIR, terminal inverted repeats; LTR, long terminal repeats (transcriptional control sequence); Gag, group antigen; Prt, protease; Pol, polymerase; Env, envelope; UTR, untranslated region; ORF, open reading frame; $\mathrm{HR}$, hexamer repeat; VNTR, variable number tandem repeats; SINE-R, Alu right monomer; SVA, SINE-R/VNTR/Alu composite; L, left monomer; R, right monomer.

Before delving into the immunological impacts of retroelements, it should be stated that the retrotransposition mechanism itself can cause genomic damage and result in human disease [50]. New retrotransposon insertions in or near exonic genes can result in altered transcription [51], disrupted mRNA splicing, premature termination of translation, and loss of protein expression or function. Besides sporadic genetic diseases [52] caused by new retrotranspositions, this biology is accelerated in malignant cells [53] and is a major contributor to the activation of oncogenes [54], the inactivation of tumor suppressors [55,56], and larger chromosomal abnormalities [50,57-59]. Retroelements are also abundant around chromosome fragile sites, such as FRA3B on chromosome 3p14 and FRA16D on chromosome 16q23 [60,61].

\subsection{HERVS}

The HERVs are the very definition of autonomous retrotransposons in that they resulted from germline infections by exogenous retroviruses that upon cell entry reversetranscribed their RNA genome and inserted it into the host cell genome. The resulting HERVs were subsequently passed on to offspring in a Mendelian fashion and most of them exist in all now living humans [62]. Transcription of such newly formed HERVs result in a polycistronic transcript that, after splicing, encodes for all the proteins necessary for the formation of new infectious virions [63]. However, because HERVs are not under positive selection pressures (but rather the opposite), they accumulate random mutations, deletions, insertions, recombinations, and other genetic alterations over evolutionary time [62]. The modern human genome does not appear to contain any fully intact and functional HERVs anymore [62,64,65], but there still are about a dozen HERVs that encode for proteins that have some, or all, of their original functions [63-67]. Some of the youngest (=most recently incorporated) HERVs can still form virions [68], even though they lack measurable infectivity.

The HERVs in our genome belong to three classes: gammaretroviruses (class I), betaretroviruses (class II), and spumaretroviruses (class III) [69]. The published literature proposes various roles for class I (HERV-E, and to a lesser extent -W, and -H) and class II (HERV-K) HERVs in autoimmune diseases [70-73]. A common denominator among these papers is the idea that their transcriptional upregulation will trigger various aspects of an antiviral immune response, including autoantibodies against retroviral proteins [74-77]. 
A popular suggestion is that HERV proteins may trigger autoimmunity by molecular mimicry $[70,78]$ through accidental similarities between these proteins and other selfproteins. However, we believe that an immune response against HERV proteins already constitutes "autoimmunity" whether any cross-reactivity exists with proteins encoded by exonic genes, or not.

It should also be kept in mind that even HERVs that have lost their ability to encode for proteins often still possess their strong transactivating long-terminal repeats (LTRs) [79], which can influence the transcription of nearby protein-coding genes [51]. This appears to be a driver of altered gene expression in cancer [80,81], where demethylated LTRs can respond to transcription factors, including those activated by sex hormones. Demethylation of LTR sequences reportedly upregulates HERV expression also in autoimmune diseases like SLE $[82,83]$. An example of this is the influence on RAB4 gene expression exerted by the demethylated LTR of a truncated class I HERV element, termed HRES-1 [78]. RAB4, in turn, downregulates surface CD4 expression, which together with the immunogenic $28-\mathrm{kDa}$ Gag protein of HRES-1 can contribute to the self-reactivity of $\mathrm{T}$ and B cells in SLE [78]. Interestingly, polymorphisms in the HRES-I LTR are associated with SLE [84].

\subsection{L1 Retrotransposons}

Intact and functional LINE retrotransposons are also autonomous in that they encode all the components needed for their own retrotransposition $[44,85,86]$. This machinery is also responsible for the retrotranspositions of the non-autonomous retrotransposons [87], and for creating all our pseudogenes [44]. Research has focused primarily on LINE-1 (or L1), which not only are abundant, but also include members that have retained all or some of their biological functions. In contrast, the LINE-2 and LINE-3 groups, although still prevalent, are all inactive, but can serve as templates for regulatory RNA species [88].

As depicted in Figure 2, the L1 transcript is bicistronic and encodes for two proteins, the 40-kDa RNA-binding protein ORF1p and the 149-kDa endonuclease [89] and reverse transcriptase ORF2p [90], which assemble in approximately a 20:1 stoichiometry into complexes with high affinity for RNA, particularly L1 mRNA, but also Alu RNA and other small RNAs [85]. To execute retrotransposition, these ORF1p/ORF2p/RNA translocate to the nucleus, where the endonuclease activity of ORF2p cuts the genome at a poly-dT tract, allowing the poly-A tail of the L1 transcript to align, enabling the reverse transcriptase activity of ORF2p to synthesize a cDNA copy of the associated RNA, followed by DNA repair [85] (Figure 2). As a result, the genome now has a new 6-kb L1 element identical to the one that created it. New Alu elements and pseudogenes are generated by the exact same mechanism [44].

While there is presently no conclusive evidence that retrotransposition of L1 plays any role in autoimmunity (and no evidence that it does not), there are several other aspects of L1 biology that make these elements prime suspects in the pathogenesis of SLE and related autoimmune diseases characterized by elevated type I IFNs.

\subsection{Non-Autonomous Retroelements}

The enormous abundance of Alu elements with over one million copies throughout our genome, all generated by the L1 retrotransposition machinery, bears witness to the period of very active genome remodeling during hominid evolution. Alu elements are found abundantly within introns and in regulatory regions of genes and in intergenic space. The generation of new Alu and SVA elements is still ongoing and can result in positive or negative changes in the transcriptional control of genes. As such, this mechanism can contribute to human disease, conceivably including autoimmune diseases like lupus. An example of this was the discovery of an Alu insertion into an intron of the FAS/CD95 gene, which resulted in mis-splicing of its transcript, loss of functional FAS protein, and lymphoproliferative disease [91]. Alu transcripts also have the potential to form double-stranded structures, which can be recognized by RNA sensors to induce type I IFNs [92]. This danger is normally reduced by adenosine-to-inosine editing by the ADAR1 
enzyme [93], the loss of which causes the interferonopathy Aicardi-Goutières syndrome, discussed in Section 3.2. This RNA editing also appears to be defective in patients with multiple sclerosis [94].

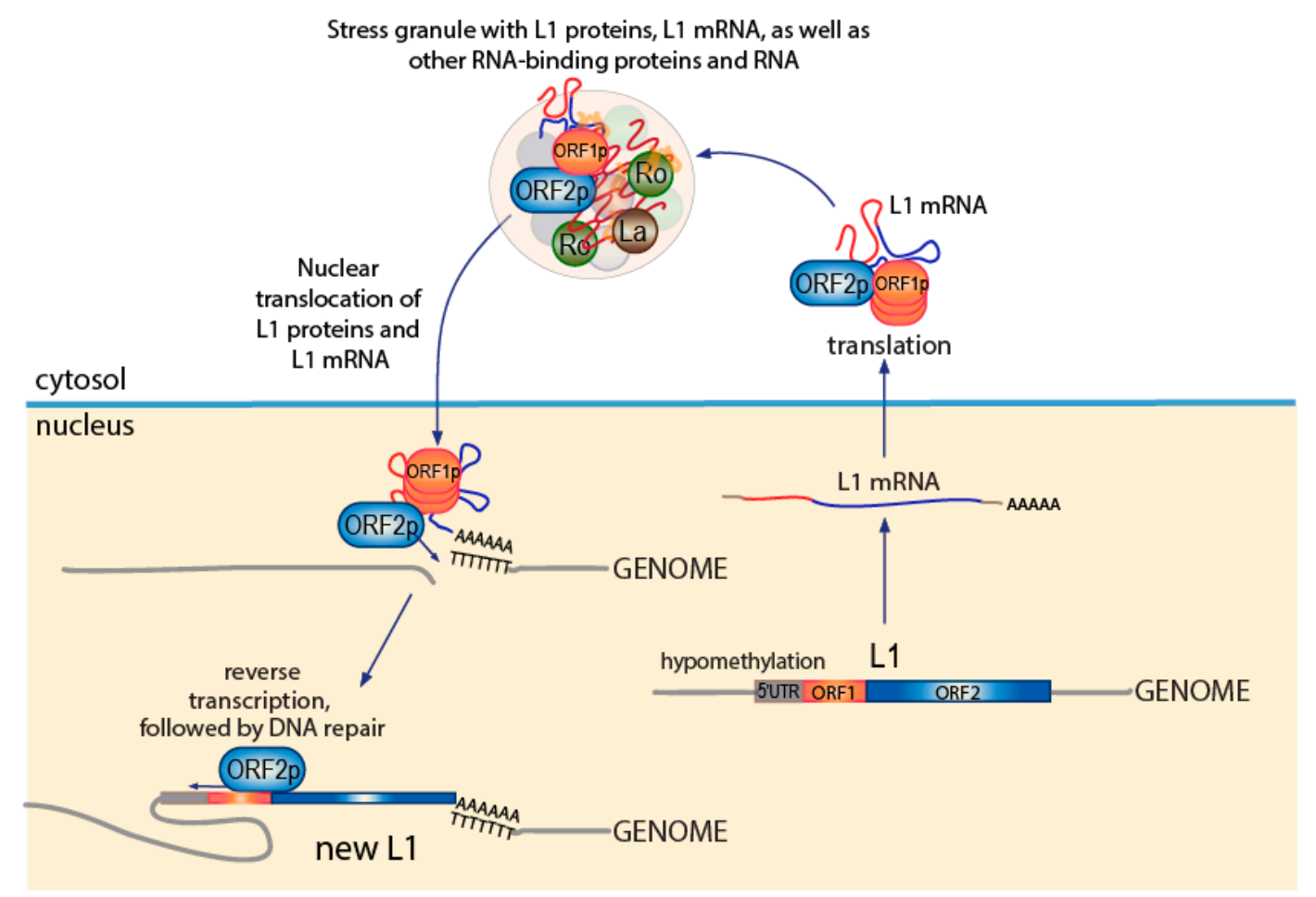

Figure 2. The L1 retrotransposition process. A similar figure is in [40].

Alu elements have also gained interest in lupus research due to the association of Aluderived RNA with Ro60 [95-97], a well-recognized SLE autoantigen. In a 2015 paper [97], immune complexes formed by anti-Ro60 autoantibodies where isolated from SLE patients and the bound RNA sequenced, revealing that much of it was Alu- and L1-derived. We will discuss the protein and RNA complexes that contain Ro60, known as stress granules, more below.

\section{How L1 Retrotransposons May Trigger IFN-Positive SLE}

There are several reasons to ask whether L1 retrotransposons play an important role in the pathogenesis and flares of SLE. Increased L1 transcripts and ORF1p protein have been detected in kidney biopsies from patients with lupus nephritis and in salivary gland biopsies from Sjögren's syndrome patients [98]. In healthy individuals, L1 transcripts are low or undetectable, but can be induced by demethylating drugs like 5-aza-deoxycytosine [99], including those known to cause drug-induced lupus $[100,101]$, e.g., hydralazine and procainamide. Reduced methylation of the 5' regulatory ("promoter") region of L1 has been reported in both adult and pediatric lupus patients [102]. UV light, a well-known trigger of lupus flares $[103,104]$, also causes DNA demethylation, in addition to causing direct DNA damage and cell death at higher exposures. L1 expression also responds to other environmental and microbial factors $[105,106]$.

Essentially all patients with SLE have IgG autoantibodies against ORF1p [107,108], which correlate with disease activity measured by the SLE disease activity index (SLEDAI), the presence of lupus nephritis, complement consumption, increased anti-dsDNA, and higher type I IFN activity [107]. Importantly, there anti-ORF1p autoantibodies do not represent anti-DNA reactivity, as free dsDNA did not compete (while free ORF1p did), DNase treatment did not affect them (while it eliminated anti-dsDNA reactivity), and ORF1p was recognized even when mixed with whole cell lysates. Presumably related to 
this finding, ORF1p and ORF2p reside in cells in macromolecular assemblies referred to as "stress-granules" [109], which are rich in RNA and RNA-binding proteins, including Ro60 and other SLE autoantigens [110].

Importantly, L1 expression has been shown to induce type I IFNs [111-113], which are a hallmark of SLE [114-118]. This can reportedly occur by two different mechanism [111-113,119], which are not mutually exclusive: (i) cytosolic DNA generated by reverse transcription by ORF2p activates DNA sensors [111], such as cyclic guanosine adenosine monophosphate synthase (cGAS), which through the stimulator of interferon genes (STING) adapter protein [120] activates the TBK1 protein kinase [121], which phosphorylates the IRF3 transcription factor leading to type 1 IFN production. Indeed, cGAS activation was documented in some $17 \%$ of SLE in a recent study [122]; (ii) double-stranded RNA species [113], perhaps related to bidirectional L1 promoter activity, activates RNA sensors that initiate the same kinase-transcription factor pathway to type I IFNs. While this second pathway is not restricted to L1 transcripts, either, or both, of these mechanisms can explain the elevated expression of IFN-inducible genes, referred to as the "IFN signature" $[116,123]$ in SLE and related autoimmune diseases, such as idiopathic inflammatory myopathies and primary Sjögren's syndrome [124].

Taking all these observations together, it appears that L1 elements with intact ORF1 and ORF2 are derepressed by reduced DNA methylation (and other epigenetic mechanisms that depend on it) and, therefore, transcribed at elevated levels compared to healthy individuals. Indeed, decreased DNA methylation has been documented in SLE, including specifically in the $5^{\prime}$ regulatory regions of L1 [102]. However, there are also reports that L1 methylation is not altered, but one has to keep in mind that such measures are a composite of numerous L1 elements and does not necessarily represent the relatively small number of L1 loci that are transcriptionally activated in SLE. The epigenetic regulation of L1 elements also varies between cell types. Even different immune cell lineages have distinct patterns of active L1 elements (our unpublished observation).

Translation of these elevated L1 transcripts leads to accumulation of ORF1p and ORF2 $p$ in stress granules [109], which, because they contain immunogenic ORF1p protein and lots of RNA, seem to be of special interest to the immune system in SLE patients. We surmise that cells expressing L1, containing triggered DNA and/or RNA sensors, and producing type I IFNs, will appear virally infected to the host immune system and drive a chronic and/or episodic systemic inflammation, which will escalate every time L1 transcription increases. Since the culprit L1 elements cannot be eradicated from the genome, the frustrated immune response will increase in magnitude with time and eventually be diagnosed as SLE.

This model (Figure 3) illustrates how L1 may contribute to many of the well-recognized aspects of SLE: its long prediagnosis development [125] and gradual presentation, its unpredictable and relapsing/remitting nature, the high type I interferons, its sensitivity to demethylating drugs and UV, and the focus of the autoimmune response towards nucleic acids and proteins associated with them. These features also explain the typical symptoms of SLE, such as fever, fatigue, arthralgias, and the multitude of organ manifestations related to the accumulation of immune complexes.

\subsection{HERVs and Other Non-L1 Retrotransposons in SLE}

Elevated expression $[67,126]$ of many HERVs and autoantibodies against HERV-K and HERV-E Gag and Env proteins [40,72,74-76] have been reported in SLE [127] and other autoimmune diseases [71]. The broader genomic hypomethylation observed in SLE may well explain the upregulation of HERV transcription, but since most HERVs have lost their ability to encode full-length retroviral proteins, only a few of these transcripts are capable of supporting autoantibody production. The resulting autoantibodies may synergize with anti-L1 immunity, for example, in the formation of immune complexes that drive tissue inflammation and organ damage. HERVs with an intact pol gene, encoding for their reverse transcriptase, can, in principle, produce DNA species that trigger DNA sensors like cGAS 
or ZBP-1 to induce type I IFN production. However, the retroviral life-cycle involves a protected reverse transcription of the RNA genome only upon cell entry and in the confines of the nucleocapsid [128,129]. Hence, HERVs are not likely to generate pathogenic DNA in SLE, but they may well generate double-stranded RNA transcripts that can trigger RNA sensors.

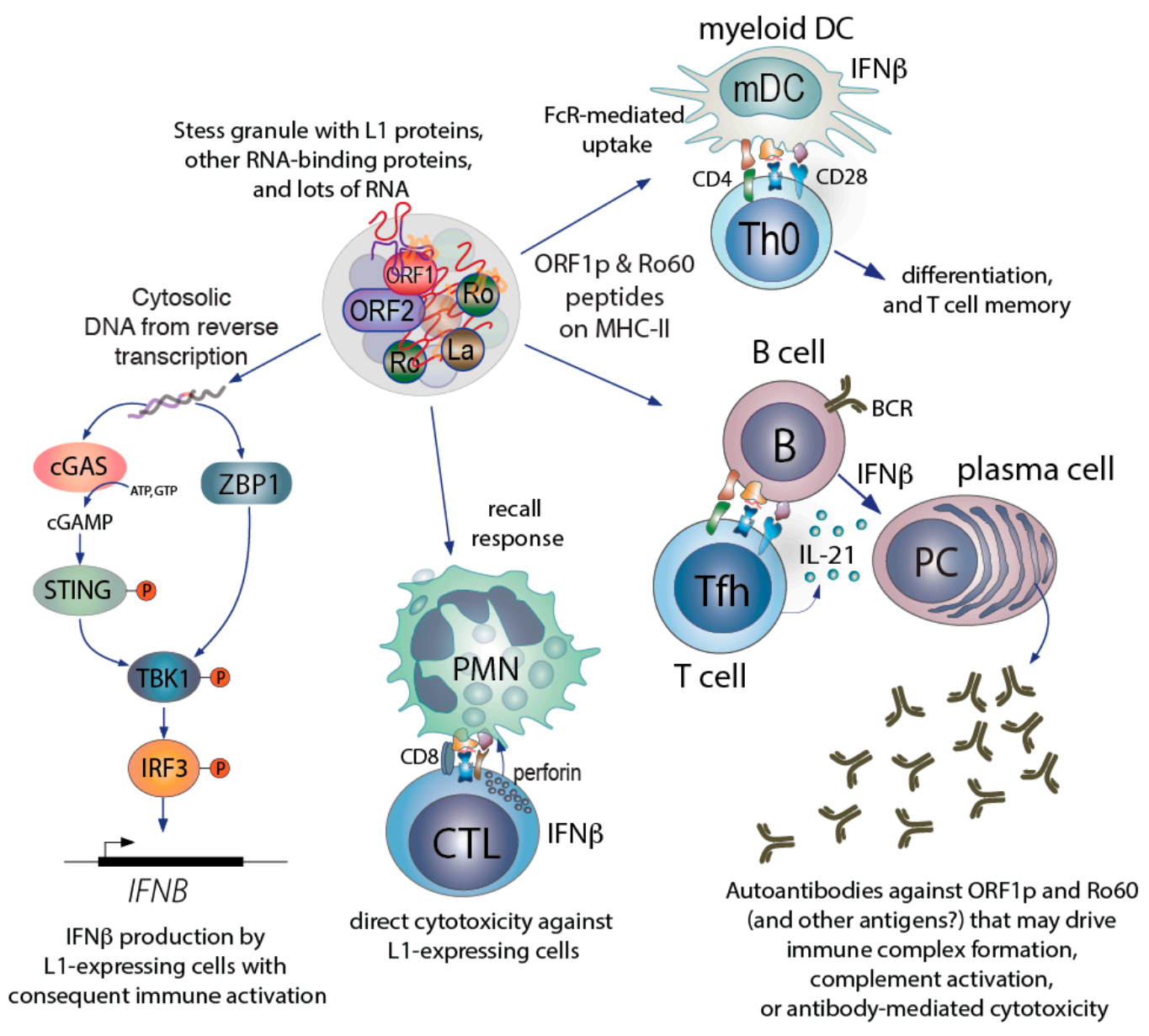

Figure 3. How the L1-containing stress granule may participate in driving SLE-related autoimmunity. The initial priming of T cells likely occurs by dendritic cells, which can take up stress granules, process their contents, and present peptides on class II MHC. The production of autoantibodies against ORF1p and Ro60 likely involves T cells primed by DC, followed by differentiation into follicular or peripheral helper T cells. CD8 T cells derived by cross-priming likely can recognized L1-expressing cells by virtue of ORF1p (and Ro60) derived peptides on class I MHC. Intracellularly, the reverse transcription of L1 transcripts into DNA will trigger IFN $\beta$ production and secretion. The secreted IFN $\beta$ will further stimulate monocyte differentiation to myeloid DC, plasma cell differentiation, and the differentiation and activation of CD8 T cells to become cytotoxic. Some cells do not express cGAS, but instead have other DNA sensors, such as Z-DNA binding protein 1, ZBP1, which also induce IFN $\beta$ production. Lastly (and not specifically illustrated), immune complexes that contain ORF1p, Ro60, and RNA (i.e., stress granules) will be taken up by plasmacytoid dendritic cells and B cells to trigger TLR-mediated IFN $\alpha$ production.

\subsection{Are Defenses Against L1 and HERVs Defective in SLE?}

Although many components of the model presented above are well documented, it still contains significant gaps. Why does L1 become hypomethylated in individuals who develop SLE? Why is ORF1p so immunogenic? What prevents this from occurring in healthy individuals?

Since majority of people never develop SLE, there must be effective mechanisms to counteract the biology of L1 and HERVs to prevent their deleterious effects on our health. Indeed, numerous defenses exist against all retrotransposons [130,131], many 
discovered during research into the infectivity of human immunodeficiency virus (HIV). These defenses operate at every step of the life-cycle of retrotransposons and HERVs, and exogenous retroviruses. Some of these defense mechanisms also operate to combat other exogenous RNA and DNA viruses.

Epigenetic regulation is a fundamental mechanism employed by cells to silence genes whose actions are either not needed or are potentially deleterious [132]. This mechanism of transcriptional repression operates on L1 [132] and HERVs and is initiated by DNA methyltransferase 1 (DNMT1) [133], which methylates the 5-position of cytosine in genomic CpG islands, attracting several silencing factors such as the human silencing hub (HUSH) complex [134] and histone modifiers [135] to effectively suppress transcription. Next, RNA interference and silencing activities of small interfering RNAs (siRNAs), miRNAs, and Piwi-interacting RNAs (piRNAs) act to prevent retrotransposon mRNA translation [136]. Of these, the piRNA system is particularly important for protecting the integrity of the germline genome against retrotransposons $[137,138]$.

Hypomethylation of the genome [139] and specific hypomethylation of L1 elements and HERVs have been documented in SLE [140,141] and Sjögren's syndrome [139,141]. The epigenetic mechanisms of L1 repression may also be influenced by environmental factors [142,143]. It is intriguing that drugs known to cause drug-induced lupus, such as hydralazine and procainamide [144,145], and UV light exposure (a well-known trigger of lupus flares [104]), are demethylating agents [146] and increase L1 and HERV expression.

In concert with the above mechanisms, the cytosolic DNase TREX1 [147] and the heterotrimeric RNaseH2 enzyme [148] act to remove cytosolic DNA [15] and RNA species, respectively. Both enzymes are particularly active against DNA:RNA hybrids [149], the intermediate stage of reverse transcription. Indeed, loss of TREX1 results in accumulation of L1-catalyzed DNA in cytosolic granules $[149,150]$. The importance of these nucleic acid degrading enzymes is perhaps best illustrated by their loss-of-function mutations [151] in Aicardi-Goutières syndrome (AGS) a devastating disease characterized by constitutively high production of type I IFNs, neurologic deficits due to IFN toxicity, and autoimmunity with all the hallmarks and autoantibodies of SLE [152]. L1 expression is high in AGS [153] and type I IFN production can be reduced by administering reverse transcriptase inhibitors that are active against ORF2p [154]. The form of SLE caused by TREX1 mutations [13] likely involves the same overproduction of ORF2p-generated DNA.

The function of retrotransposon proteins is also targeted by defense mechanisms, such as translational inhibition by the ATP-dependent RNA helicase Moloney leukemia virus 10 (MOV10) protein [155-157], which coexists with ORF1p in stress granules [110]. Exactly how MOV10 works is not well understood. Another L1-associated protein identified by proteomics $[110,158]$ is zinc finger CCHC domain-containing 3 (ZCCHC3), a cofactor for both DNA and RNA sensors $[159,160]$. The SAMHD1 gene, loss-of-function mutations of which also lead to AGS [161], encodes a phosphohydrolase that dephosphorylates the deoxy-nucleotide triphosphates required for reverse transcription. In addition, the retrotransposition process is directly disrupted by mutation-inducing members of the apolipoprotein B mRNA editing catalytic polypeptide-like 3 (APOBEC3) family of enzymes [162,163], which deaminate cytosines to uracil, and adenosine deaminase of RNA 1 (ADAR1) [93], which deaminates adenosines to inosine. As a result of these mechanisms, the majority of all retrotranspositions result in mutated and severely $5^{\prime}$ truncated new copies (reverse transcription starts in the $3^{\prime}$ end). Most importantly, these mechanisms counteract the production of IFN-inducing DNA and other aspects of L1 biology that can lead to immune activation. Future work will determine if any of these mechanisms are defective in SLE.

\subsection{Subsets of SLE with Distinct Mechanisms}

The therapeutic options for the management of SLE are limited and often fail to control the disease without unacceptable adverse events. Numerous candidate drugs have failed in clinical trials, for reasons that likely include its molecular heterogeneity and the inaccuracy 
of tools to assess disease activity. It is quite possible that no single drug will be effective and safe in all SLE patients, but that the precision medicine concept of "the right medicine for the right patient" is particularly relevant in SLE.

Based on biochemical and available clinical trial data, we proposed recently that SLE consists of at least four distinct molecular "endotypes" [164]. The first of these is the IFNindependent form of SLE, "SLE1", defined as the patients who meet the diagnostic criteria for SLE, but consistently lack an IFN signature, i.e., IFN-induced genes are expressed at normal low levels. The remaining three endotypes are characterized by a positive IFN signature, but differ in which nucleic acid sensors have been activated and, consequently, which isotypes of type I IFNs are overproduced.

We define SLE2 as the form in which extracellular immune complexes that contain nucleic acids (e.g., L1-containing stress granules) activate endosomal toll-like receptors (TLRs) 3, 7, 8, or 9 to induce type I IFN production [165]. Due to the predominant expression of TLRs in immune cells, particularly plasmacytoid [166], but also myeloid dendritic cells, macrophages, monocytes, and B cells, the spectrum of induced IFNs include numerous isotypes of IFN $\alpha$ with lesser contributions by IFN $\beta$ and type III IFNs [123]. This form of SLE was previously thought to be the main form [167], but the failures in phase 2 clinical trials of multiple TLR7/9 antagonists and antibodies like rontalizumab and sifalimumab that effectively neutralize IFN $\alpha$, indicate that only $10 \%$ or less of SLE patients have SLE2. Most telling, the elevated IFN-inducible genes in the blood of treated patients only declined marginally in patients treated with sifalimumab.

SLE3 is an IFN $\beta$-predominant endotype with activated cytosolic DNA and/or RNA sensors, representing the two alternative mechanisms by which L1 can drive type I IFNs. This biology can occur in any cell type that expresses L1 and/or produces pathogenic double-stranded RNA and this is also how exogenous DNA or RNA viruses initiate an antiviral immune response.

We consider it plausible that SLE typically starts as a pure SLE3 endotype, but that the immune response eventually escalates to a stage where circulating immune complexes with L1-containing, or other, RNA-rich particles accumulate and begin to trigger TLRs on immune cells, i.e., inducing the SLE2 endotype mechanism for type I IFN production. We designated this overlap as SLE4, in which all type I IFNs are at play and both cytosolic and endosomal nucleic acid sensors are active. We estimated that SLE1 represents 10-30\%, SLE2 less than $10 \%$, and SLE3 and SLE4 together $60-80 \%$ of all SLE patients.

Support for this molecular classification comes from clinical trials with drugs that target IFNs, such as rontalizumab (anti-IFN $\alpha$ ), sifalimumab (anti-IFN $\alpha$ ), and anifrolumab (antitype I IFN receptor) [168-170], bearing in mind that average outcomes are not as illuminating as a more detailed responder vs. non-responder assessment. Indeed, it is likely that many clinical trial failures in SLE, e.g., with TLR7 antagonists, are the results of too few patients of the responding endotype. In this scenario, the patients with nonresponding endotypes diluted out the therapeutic effects beyond the statistical analysis of the entire intent-to-treat cohort.

\subsection{L1- and HERV-Related Biomarkers}

Whether the above classification is relevant or not, SLE is clearly a heterogeneous disease in its clinical manifestations and response to therapy [1,2]. Many tools have been developed and revised over the years to help guide the diagnosis and management of patients with SLE, and to measure therapeutic effects of drugs during clinical trials. They include various high-sensitivity and high-specificity clinical- and laboratory-based classification criteria (e.g., SLICC criteria) and disease activity indices (e.g., SLEDAI). Despite all these tools, however, the management of SLE, especially in severe disease states, remains one of the biggest challenges in rheumatology. There is often discordance between laboratory evidence of immunologic activity and clinical evidence of disease activity. New diagnostic tools or biomarkers might help narrow the gap. 
As we recently demonstrated, the titers of IgG autoantibodies against L1 ORF1p correlate significantly with disease phenotypes, SLEDAI, markers of disease activity, and IFN score [107]. These autoantibodies could conceivably aid in the diagnosis and prognosis of the disease, perhaps guiding which endotype of SLE an individual patient has and, hence, which treatment regimen might be most effective. High titers of anti-ORF1p autoantibodies may also help identify patients who progress to end organ damage, such as lupus nephritis, and may benefit from earlier optimization of their treatment. This would need to be rigorously tested in prospective clinical studies.

Another set of biomarkers would be tests for the activation of the DNA and RNA sensors. Quantitation of the unique second messenger that cGAS produces, cyclic-guanosine adenosine-2,3-monophosphate (cGAMP) by mass spectrometry is probably too cumbersome for use in clinical practice, but newer high-sensitivity ELISAs are under development. For example, it would make sense to consider cGAS inhibitors specifically in those patients that are positive for cGAMP. Another biomarker to reveal the activation of the RNA sensors could be useful. When triggered, these sensors cause the oligomerization of the mitochondrial antiviral signaling (MAVS) adaptor protein, a response that is readily detectable on non-denaturing gels as an ultrahigh-molecular weight species [171]. Representative individual isotypes of the 17 type I IFNs can be quantitated by the ultra-sensitive single-molecule array (SIMOA) platform [172].

\subsection{Novel Therapeutic Opportunities Related to L1}

New effective and safe drugs are urgently needed for SLE. It stands to reason that drugs that selectively interfere with the molecular pathways that drive SLE, rather than broadly suppress the immune system, would be both more effective and better tolerated than current treatments. The L1 mechanisms we discussed above offer a new option, at least for the SLE3 and SLE4 endotypes, namely the inhibition of ORF2p-catalyzed reverse transcription, which is upstream of type I IFN production, and all the other biological responses induced by activated DNA sensors, such as the upregulation of MHC and costimulatory molecules. Of the FDA-approved reverse transcriptase inhibitors used for the treatment of HIV, some nucleoside RTIs (NRTIs) are equally or near-equally potent on ORF2p as on HIV RT, while others, including the non-nucleoside reverse transcriptase inhibitors, are not. Studies in Trex1-deficient mice, which suffer from severe autoimmune myocarditis and high type I IFNs similar to AGS, have shown that these mice can be rescued by treatment with a three-drug NRTI combination (emtricitabine, tenofovir, and nevirapine). Even more striking, patients with AGS treated with an FDA-approved threedrug NRTI regimen (abacavir, lamivudine, and zidovudine) showed marked reduction in the levels of IFN $\alpha$ proteins and IFN-inducible genes, and an improvement in cerebral blood flow. Several other novel treatments are being explored for AGS, as well as SLE, including inhibitors of cGAS [173], and tyrosine kinase 2 (TYK2), which mediates IFN receptor signaling. Notably, the suppression of inflammation mediated by type I IFNs (potentially triggered by L1 DNA) is a common theme among these potential SLE therapies.

Based on the biology of L1 and HERVs, agents that promote genomic CpG island methylation or other suppressive epigenetic events, or that prevent the translation of their transcripts, e.g., siRNAs, could also be developed for a more uniquely targeted treatment of SLE. The testing of such agents would also go a long way to validate, or refute, the pathogenic relevance of retrotransposons. Lastly, to the best of our knowledge, there is nothing in the drug development pipeline specifically for type I IFN-independent SLE, which mechanistically remains an enigma.

\section{Concluding Remarks}

The very modest successes in SLE drug development in modern times, and the shortcomings of mainstream models for its etiopathogenesis, make it apparent that new ideas are needed. A more reliable early diagnosis, more accurate prognostication, and the development of more effective treatments with better safety profiles, are all highly needed. 
To this end, the emerging evidence of endogenous retroelement involvement in SLE offers a tantalizing promise of progress.

While a broader set of retrotransposons may have varying degrees of involvement in initiating and perpetuating SLE and its flares, current evidence suggests that the L1 retrotransposon is likely the most consequential. However, a true causative role will need to be demonstrated by clinical trials using drugs that interfere with relevant aspects of L1 biology, e.g., reverse transcriptase inhibitors.

Author Contributions: K.C.U. and T.M. contributed equally to the writing of this review and share accountability for its content. All authors have read and agreed to the published version of the manuscript.

Funding: This research was funded by NIH, research grants T32 AR007108 to K.C.U., and R21 AR075134, R21 AR077266 and R01 AR074939 to T.M.

Institutional Review Board Statement: Our work with patient samples has been approved by the University of Washington Institutional Review Board, approval number STUDY00006196, and informed written consent was obtained from all participants according to the Declaration of Helsinki.

Informed Consent Statement: Not applicable.

Data Availability Statement: Not applicable.

Acknowledgments: We thank John LaCava, Marty Taylor, and Christian Lood for valuable suggestions and discussions.

Conflicts of Interest: K.C.U. declares no financial conflicts of interest. T.M. has received consulting fees from Cugene, Kiniksa, Miro Bio, and QiLu Pharmaceuticals, research funding from Gilead Sciences, and has an ownership share in Amdax. These organizations had no role in the design of our studies; in the collection, analyses, or interpretation of data; in the writing of this manuscript, or in the decision to publish study results.

\section{References}

1. Wang, L.; Wang, F.S.; Gershwin, M.E. Human autoimmune diseases: A comprehensive update. J. Intern. Med. 2015, 278, 369-395. [CrossRef] [PubMed]

2. Lockshin, M.D.; Barbhaiya, M.; Izmirly, P.; Buyon, J.P.; Crow, M.K. SLE: Reconciling heterogeneity. Lupus Sci. Med. 2019, 6, e000280. [CrossRef]

3. Rullo, O.J.; Tsao, B.P. Recent insights into the genetic basis of systemic lupus erythematosus. Ann. Rheum. Dis. 2013, 72 (Suppl. S2), ii56-ii61. [CrossRef]

4. Hom, G.; Graham, R.R.; Modrek, B.; Taylor, K.E.; Ortmann, W.; Garnier, S.; Lee, A.T.; Chung, S.A.; Ferreira, R.C.; Pant, P.V.; et al. Association of systemic lupus erythematosus with C8orf13-BLK and ITGAM-ITGAX. N. Engl. J. Med. 2008, 358, 900-909. [CrossRef]

5. Graham, R.R.; Hom, G.; Ortmann, W.; Behrens, T.W. Review of recent genome-wide association scans in lupus. J. Intern. Med. 2009, 265, 680-688. [CrossRef]

6. Nath, S.K.; Han, S.; Kim-Howard, X.; Kelly, J.A.; Viswanathan, P.; Gilkeson, G.S.; Chen, W.; Zhu, C.; McEver, R.P.; Kimberly, R.P.; et al. A nonsynonymous functional variant in integrin-alpha(M) (encoded by ITGAM) is associated with systemic lupus erythematosus. Nat. Genet. 2008, 40, 152-154. [CrossRef] [PubMed]

7. Boackle, S.A. Advances in lupus genetics. Curr. Opin. Rheumatol. 2013, 25, 561-568. [CrossRef] [PubMed]

8. Barcellos, L.F.; May, S.L.; Ramsay, P.P.; Quach, H.L.; Lane, J.A.; Nititham, J.; Noble, J.A.; Taylor, K.E.; Quach, D.L.; Chung, S.A.; et al. High-density SNP screening of the major histocompatibility complex in systemic lupus erythematosus demonstrates strong evidence for independent susceptibility regions. PLoS Genet. 2009, 5, e1000696. [CrossRef]

9. International MHC, and Autoimmunity Genetics Network; Rioux, J.D.; Goyette, P.; Vyse, T.J.; Hammarstrom, L.; Fernando, M.M.; Green, T.; De Jager, P.L.; Foisy, S.; Wang, J.; et al. Mapping of multiple susceptibility variants within the MHC region for 7 immune-mediated diseases. Proc. Natl. Acad. Sci. USA 2009, 106, 18680-18685. [CrossRef] [PubMed]

10. Graham, R.R.; Ortmann, W.; Rodine, P.; Espe, K.; Langefeld, C.; Lange, E.; Williams, A.; Beck, S.; Kyogoku, C.; Moser, K.; et al. Specific combinations of HLA-DR2 and DR3 class II haplotypes contribute graded risk for disease susceptibility and autoantibodies in human SLE. Eur. J. Hum. Genet. 2007, 15, 823-830. [CrossRef]

11. Bowness, P.; Davies, K.A.; Norsworthy, P.J.; Athanassiou, P.; Taylor-Weideman, J.; Borysiewicz, L.K.; Meyer, P.A.R.; Walport, M.J. Hereditary C1q deficiency and systemic lupus erythematosus. Quart. J. Med. 1994, 87, 455-464.

12. Truedsson, L.; Bengtsson, A.A.; Sturfelt, G. Complement deficiencies and systemic lupus erythematosus. Autoimmunity 2007, 40, 560-566. [CrossRef] [PubMed] 
13. Namjou, B.; Kothari, P.H.; Kelly, J.A.; Glenn, S.B.; Ojwang, J.O.; Adler, A.; Alarcon-Riquelme, M.E.; Gallant, C.J.; Boackle, S.A.; Criswell, L.A.; et al. Evaluation of the TREX1 gene in a large multi-ancestral lupus cohort. Genes Immun. 2011, 12, 270-279. [CrossRef]

14. Gaipl, U.S.; Beyer, T.D.; Heyder, P.; Kuenkele, S.; Bottcher, A.; Voll, R.E.; Kalden, J.R.; Herrmann, M. Cooperation between C1q and DNase I in the clearance of necrotic cell-derived chromatin. Arthritis Rheum. 2004, 50, 640-649. [CrossRef] [PubMed]

15. Stetson, D.B.; Ko, J.S.; Heidmann, T.; Medzhitov, R. Trex1 prevents cell-intrinsic initiation of autoimmunity. Cell 2008, 134, 587-598. [CrossRef] [PubMed]

16. Al-Mayouf, S.M.; Sunker, A.; Abdwani, R.; Abrawi, S.A.; Almurshedi, F.; Alhashmi, N.; Al Sonbul, A.; Sewairi, W.; Qari, A.; Abdallah, E.; et al. Loss-of-function variant in DNASE1L3 causes a familial form of systemic lupus erythematosus. Nat. Genet. 2011, 43, 1186-1188. [CrossRef] [PubMed]

17. Bronson, P.G.; Chaivorapol, C.; Ortmann, W.; Behrens, T.W.; Graham, R.R. The genetics of type I interferon in systemic lupus erythematosus. Curr. Opin. Immunol. 2012, 24, 530-537. [CrossRef]

18. Kariuki, S.N.; Kirou, K.A.; MacDermott, E.J.; Barillas-Arias, L.; Crow, M.K.; Niewold, T.B. Cutting edge: Autoimmune disease risk variant of STAT4 confers increased sensitivity to IFN-alpha in lupus patients in vivo. J. Immunol. 2009, 182, 34-38. [CrossRef]

19. Banchereau, R.; Hong, S.; Cantarel, B.; Baldwin, N.; Baisch, J.; Edens, M.; Cepika, A.M.; Acs, P.; Turner, J.; Anguiano, E.; et al. Personalized Immunomonitoring Uncovers Molecular Networks that Stratify Lupus Patients. Cell 2016, 165, 551-565. [CrossRef]

20. Niewold, T.B.; Kelly, J.A.; Flesch, M.H.; Espinoza, L.R.; Harley, J.B.; Crow, M.K. Association of the IRF5 risk haplotype with high serum interferon-alpha activity in systemic lupus erythematosus patients. Arthritis Rheum. 2008, 58, 2481-2487. [CrossRef]

21. Kariuki, S.N.; Crow, M.K.; Niewold, T.B. The PTPN22 C1858T polymorphism is associated with skewing of cytokine profiles toward high interferon-alpha activity and low tumor necrosis factor alpha levels in patients with lupus. Arthritis Rheum. 2008, 58, 2818-2823. [CrossRef] [PubMed]

22. Gorman, J.A.; Hundhausen, C.; Errett, J.S.; Stone, A.E.; Allenspach, E.J.; Ge, Y.; Arkatkar, T.; Clough, C.; Dai, X.; Khim, S.; et al. The A946T variant of the RNA sensor IFIH1 mediates an interferon program that limits viral infection but increases the risk for autoimmunity. Nat. Immunol. 2017, 18, 744-752. [CrossRef] [PubMed]

23. Tian, J.; Ma, Y.; Li, J.; Cen, H.; Wang, D.G.; Feng, C.C.; Li, R.J.; Leng, R.X.; Pan, H.F.; Ye, D.Q. The TLR7 7926A>G polymorphism is associated with susceptibility to systemic lupus erythematosus. Mol. Med. Rep. 2012, 6, 105-110. [CrossRef]

24. Prokunina, L.; Castillejo-Lopez, C.; Oberg, F.; Gunnarsson, I.; Berg, L.; Magnusson, V.; Brookes, A.J.; Tentler, D.; Kristjansdottir, H.; Grondal, G.; et al. A regulatory polymorphism in PDCD1 is associated with susceptibility to systemic lupus erythematosus in humans. Nat. Genet. 2002, 32, 666-669. [CrossRef] [PubMed]

25. Kozyrev, S.V.; Abelson, A.K.; Wojcik, J.; Zaghlool, A.; Linga Reddy, M.V.; Sanchez, E.; Gunnarsson, I.; Svenungsson, E.; Sturfelt, G.; Jonsen, A.; et al. Functional variants in the B-cell gene BANK1 are associated with systemic lupus erythematosus. Nat. Genet. 2008, 40, 211-216. [CrossRef] [PubMed]

26. Namjou, B.; Kim-Howard, X.; Sun, C.; Adler, A.; Chung, S.A.; Kaufman, K.M.; Kelly, J.A.; Glenn, S.B.; Guthridge, J.M.; Scofield, R.H.; et al. PTPN22 association in systemic lupus erythematosus (SLE) with respect to individual ancestry and clinical sub-phenotypes. PLoS ONE 2013, 8, e69404. [CrossRef]

27. Curran, C.S.; Gupta, S.; Sanz, I.; Sharon, E. PD-1 immunobiology in systemic lupus erythematosus. J. Autoimmun. 2019, 97, 1-9. [CrossRef]

28. Jiang, S.H.; Athanasopoulos, V.; Ellyard, J.I.; Chuah, A.; Cappello, J.; Cook, A.; Prabhu, S.B.; Cardenas, J.; Gu, J.; Stanley, M.; et al. Functional rare and low frequency variants in BLK and BANK1 contribute to human lupus. Nat. Commun. 2019, $10,2201$. [CrossRef]

29. Jacquemin, C.; Schmitt, N.; Contin-Bordes, C.; Liu, Y.; Narayanan, P.; Seneschal, J.; Maurouard, T.; Dougall, D.; Davizon, E.S.; Dumortier, H.; et al. OX40 Ligand Contributes to Human Lupus Pathogenesis by Promoting T Follicular Helper Response. Immunity 2015, 42, 1159-1170. [CrossRef]

30. Orru, V.; Tsai, S.J.; Rueda, B.; Fiorillo, E.; Stanford, S.M.; Dasgupta, J.; Hartiala, J.; Zhao, L.; Ortego-Centeno, N.; D’Alfonso, S.; et al. A loss-of-function variant of PTPN22 is associated with reduced risk of systemic lupus erythematosus. Hum. Mol. Genet. 2009, 18, 569-579. [CrossRef]

31. Hawn, T.R.; Wu, H.; Grossman, J.M.; Hahn, B.H.; Tsao, B.P.; Aderem, A. A stop codon polymorphism of Toll-like receptor 5 is associated with resistance to systemic lupus erythematosus. Proc. Natl. Acad. Sci. USA 2005, 102, 10593-10597. [CrossRef]

32. Altorok, N.; Sawalha, A.H. Epigenetics in the pathogenesis of systemic lupus erythematosus. Curr. Opin. Rheumatol. 2013, 25, 569-576. [CrossRef] [PubMed]

33. Costenbader, K.H.; Gay, S.; Alarcon-Riquelme, M.E.; Iaccarino, L.; Doria, A. Genes, epigenetic regulation and environmental factors: Which is the most relevant in developing autoimmune diseases? Autoimmun. Rev. 2012, 11, 604-609. [CrossRef] [PubMed]

34. Yeung, K.S.; Chung, B.H.; Choufani, S.; Mok, M.Y.; Wong, W.L.; Mak, C.C.; Yang, W.; Lee, P.P.; Wong, W.H.; Chen, Y.A.; et al Genome-Wide DNA Methylation Analysis of Chinese Patients with Systemic Lupus Erythematosus Identified Hypomethylation in Genes Related to the Type I Interferon Pathway. PLoS ONE 2017, 12, e0169553. [CrossRef] [PubMed]

35. Patel, D.R.; Richardson, B.C. Dissecting complex epigenetic alterations in human lupus. Arthritis Res. Ther. 2013, 15, 201. [CrossRef]

36. Shen, N.; Liang, D.; Tang, Y.; de Vries, N.; Tak, P.P. MicroRNAs-novel regulators of systemic lupus erythematosus pathogenesis. Nat. Rev. Rheumatol. 2012, 8, 701-709. [CrossRef] [PubMed] 
37. Stetson, D.B. Endogenous retroelements and autoimmune disease. Curr. Opin. Immunol. 2012, 24, 692-697. [CrossRef]

38. Crow, M.K. Long interspersed nuclear elements (LINE-1): Potential triggers of systemic autoimmune disease. Autoimmunity 2010, 43, 7-16. [CrossRef]

39. Tugnet, N.; Rylance, P.; Roden, D.; Trela, M.; Nelson, P. Human Endogenous Retroviruses (HERVs) and Autoimmune Rheumatic Disease: Is There a Link? Open Rheumatol. J. 2013, 7, 13-21. [CrossRef]

40. Mustelin, T.; Ukadike, K.C. How Retroviruses and Retrotransposons in Our Genome May Contribute to Autoimmunity in Rheumatological Conditions. Front. Immunol. 2020, 11, 593891. [CrossRef]

41. Belshaw, R.; Pereira, V.; Katzourakis, A.; Talbot, G.; Paces, J.; Burt, A.; Tristem, M. Long-term reinfection of the human genome by endogenous retroviruses. Proc. Natl. Acad. Sci. USA 2004, 101, 4894-4899. [CrossRef]

42. Nelson, P.N.; Hooley, P.; Roden, D.; Davari Ejtehadi, H.; Rylance, P.; Warren, P.; Martin, J.; Murray, P.G.; Molecular Immunology Research, G. Human endogenous retroviruses: Transposable elements with potential? Clin. Exp. Immunol. 2004, 138, 1-9. [CrossRef] [PubMed]

43. Kano, H.; Godoy, I.; Courtney, C.; Vetter, M.R.; Gerton, G.L.; Ostertag, E.M.; Kazazian, H.H., Jr. L1 retrotransposition occurs mainly in embryogenesis and creates somatic mosaicism. Genes Dev. 2009, 23, 1303-1312. [CrossRef]

44. Goodier, J.L.; Kazazian, H.H., Jr. Retrotransposons revisited: The restraint and rehabilitation of parasites. Cell 2008, 135, 23-35. [CrossRef]

45. Bourque, G.; Burns, K.H.; Gehring, M.; Gorbunova, V.; Seluanov, A.; Hammell, M.; Imbeault, M.; Izsvak, Z.; Levin, H.L.; Macfarlan, T.S.; et al. Ten things you should know about transposable elements. Genome Biol. 2018, 19, 199. [CrossRef] [PubMed]

46. Wicker, T.; Sabot, F.; Hua-Van, A.; Bennetzen, J.L.; Capy, P.; Chalhoub, B.; Flavell, A.; Leroy, P.; Morgante, M.; Panaud, O.; et al. A unified classification system for eukaryotic transposable elements. Nat. Rev. Genet. 2007, 8, 973-982. [CrossRef] [PubMed]

47. Lander, E.S.; Linton, L.M.; Birren, B.; Nusbaum, C.; Zody, M.C.; Baldwin, J.; Devon, K.; Dewar, K.; Doyle, M.; FitzHugh, W.; et al. Initial sequencing and analysis of the human genome. Nature 2001, 409, 860-921. [CrossRef] [PubMed]

48. Mandal, P.K.; Kazazian, H.H., Jr. SnapShot: Vertebrate transposons. Cell 2008, 135, 192-192.e1. [CrossRef] [PubMed]

49. Deininger, P. Alu elements: Know the SINEs. Genome Biol. 2011, 12, 236. [CrossRef]

50. Hancks, D.C.; Kazazian, H.H., Jr. Roles for retrotransposon insertions in human disease. Mob. DNA 2016, 7, 9. [CrossRef]

51. Karamitros, T.; Hurst, T.; Marchi, E.; Karamichali, E.; Georgopoulou, U.; Mentis, A.; Riepsaame, J.; Lin, A.; Paraskevis, D.; Hatzakis, A.; et al. Human Endogenous Retrovirus-K HML-2 integration within RASGRF2 is associated with intravenous drug abuse and modulates transcription in a cell-line model. Proc. Natl. Acad. Sci. USA 2018, 115, 10434-10439. [CrossRef]

52. Batista, R.L.; Yamaguchi, K.; Rodrigues, A.D.S.; Nishi, M.Y.; Goodier, J.L.; Carvalho, L.R.; Domenice, S.; Costa, E.M.F.; Kazazian, H.H.; Mendonca, B.B. Mobile DNA in Endocrinology: LINE-1 Retrotransposon Causing Partial Androgen Insensitivity Syndrome. J. Clin. Endocrinol. Metab. 2019, 104, 6385-6390. [CrossRef]

53. Ardeljan, D.; Taylor, M.S.; Ting, D.T.; Burns, K.H. The Human Long Interspersed Element-1 Retrotransposon: An Emerging Biomarker of Neoplasia. Clin. Chem. 2017, 63, 816-822. [CrossRef]

54. Xia, Z.; Cochrane, D.R.; Anglesio, M.S.; Wang, Y.K.; Nazeran, T.; Tessier-Cloutier, B.; McConechy, M.K.; Senz, J.; Lum, A.; Bashashati, A.; et al. LINE-1 retrotransposon-mediated DNA transductions in endometriosis associated ovarian cancers. Gynecol. Oncol. 2017, 147, 642-647. [CrossRef]

55. Qian, Y.; Mancini-DiNardo, D.; Judkins, T.; Cox, H.C.; Brown, K.; Elias, M.; Singh, N.; Daniels, C.; Holladay, J.; Coffee, B.; et al. Identification of pathogenic retrotransposon insertions in cancer predisposition genes. Cancer Genet. 2017, 216-217, 159-169. [CrossRef] [PubMed]

56. Scott, E.C.; Gardner, E.J.; Masood, A.; Chuang, N.T.; Vertino, P.M.; Devine, S.E. A hot L1 retrotransposon evades somatic repression and initiates human colorectal cancer. Genome Res. 2016, 26, 745-755. [CrossRef]

57. Xue, B.; Sechi, L.A.; Kelvin, D.J. Human Endogenous Retrovirus K (HML-2) in Health and Disease. Front. Microbiol. 2020, 11, 1690. [CrossRef] [PubMed]

58. Kemp, J.R.; Longworth, M.S. Crossing the LINE Toward Genomic Instability: LINE-1 Retrotransposition in Cancer. Front. Chem. 2015, 3, 68. [CrossRef]

59. Rodić, N.; Sharma, R.; Sharma, R.; Zampella, J.; Dai, L.; Taylor, M.S.; Hruban, R.H.; Iacobuzio-Donahue, C.A.; Maitra, A.; Torbenson, M.S.; et al. Long Interspersed Element-1 Protein Expression Is a Hallmark of Many Human Cancers. Am. J. Pathol. 2014, 184, 1280-1286. [CrossRef] [PubMed]

60. Ma, K.; Qiu, L.; Mrasek, K.; Zhang, J.; Liehr, T.; Quintana, L.G.; Li, Z. Common fragile sites: Genomic hotspots of DNA damage and carcinogenesis. Int. J. Mol. Sci. 2012, 13, 11974-11999. [CrossRef]

61. Fungtammasan, A.; Walsh, E.; Chiaromonte, F.; Eckert, K.A.; Makova, K.D. A genome-wide analysis of common fragile sites: What features determine chromosomal instability in the human genome? Genome Res. 2012, 22, 993-1005. [CrossRef] [PubMed]

62. Subramanian, R.P.; Wildschutte, J.H.; Russo, C.; Coffin, J.M. Identification, characterization, and comparative genomic distribution of the HERV-K (HML-2) group of human endogenous retroviruses. Retrovirology 2011, 8, 90. [CrossRef]

63. Dewannieux, M.; Harper, F.; Richaud, A.; Letzelter, C.; Ribet, D.; Pierron, G.; Heidmann, T. Identification of an infectious progenitor for the multiple-copy HERV-K human endogenous retroelements. Genome Res. 2006, 16, 1548-1556. [CrossRef]

64. Hohn, O.; Hanke, K.; Bannert, N. HERV-K(HML-2), the Best Preserved Family of HERVs: Endogenization, Expression, and Implications in Health and Disease. Front. Oncol. 2013, 3, 246. [CrossRef] 
65. Garcia-Montojo, M.; Doucet-O'Hare, T.; Henderson, L.; Nath, A. Human endogenous retrovirus-K (HML-2): A comprehensive review. Crit. Rev. Microbiol. 2018, 44, 715-738. [CrossRef]

66. Jha, A.R.; Nixon, D.F.; Rosenberg, M.G.; Martin, J.N.; Deeks, S.G.; Hudson, R.R.; Garrison, K.E.; Pillai, S.K. Human endogenous retrovirus K106 (HERV-K106) was infectious after the emergence of anatomically modern humans. PLoS ONE 2011, 6, e20234. [CrossRef]

67. Ehlhardt, S.; Seifert, M.; Schneider, J.; Ojak, A.; Zang, K.D.; Mehraein, Y. Human endogenous retrovirus HERV-K(HML-2) Rec expression and transcriptional activities in normal and rheumatoid arthritis synovia. J. Rheumatol. 2006, 33, 16-23.

68. Boller, K.; Schonfeld, K.; Lischer, S.; Fischer, N.; Hoffmann, A.; Kurth, R.; Tonjes, R.R. Human endogenous retrovirus HERV-K113 is capable of producing intact viral particles. J. Gen. Virol. 2008, 89, 567-572. [CrossRef] [PubMed]

69. Nelson, P.N.; Carnegie, P.R.; Martin, J.; Davari Ejtehadi, H.; Hooley, P.; Roden, D.; Rowland-Jones, S.; Warren, P.; Astley, J.; Murray, P.G. Demystified. Human endogenous retroviruses. Mol. Pathol. 2003, 56, 11-18. [CrossRef] [PubMed]

70. Perl, A.; Fernandez, D.; Telarico, T.; Phillips, P.E. Endogenous retroviral pathogenesis in lupus. Curr. Opin. Rheumatol. 2010, 22, 483-492. [CrossRef] [PubMed]

71. Mameli, G.; Erre, G.L.; Caggiu, E.; Mura, S.; Cossu, D.; Bo, M.; Cadoni, M.L.; Piras, A.; Mundula, N.; Colombo, E.; et al. Identification of a HERV-K env surface peptide highly recognized in Rheumatoid Arthritis (RA) patients: A cross-sectional case-control study. Clin. Exp. Immunol. 2017, 189, 127-131. [CrossRef]

72. Talotta, R.; Atzeni, F.; Laska, M.J. The contribution of HERV-E clone 4-1 and other HERV-E members to the pathogenesis of rheumatic autoimmune diseases. APMIS 2020, 128, 367-377. [CrossRef] [PubMed]

73. Karimi, A.; Esmaili, N.; Ranjkesh, M.; Zolfaghari, M.A. Expression of human endogenous retroviruses in pemphigus vulgaris patients. Mol. Biol. Rep. 2019, 46, 6181-6186. [CrossRef]

74. Bengtsson, A.; Blomberg, J.; Nived, O.; Pipkorn, R.; Toth, L.; Sturfelt, G. Selective antibody reactivity with peptides from human endogenous retroviruses and nonviral poly(amino acids) in patients with systemic lupus erythematosus. Arthritis Rheum. 1996, 39, 1654-1663. [CrossRef] [PubMed]

75. Blomberg, J.; Nived, O.; Pipkorn, R.; Bengtsson, A.; Erlinge, D.; Sturfelt, G. Increased antiretroviral antibody reactivity in sera from a defined population of patients with systemic lupus erythematosus. Correlation with autoantibodies and clinical manifestations. Arthritis Rheum. 1994, 37, 57-66. [CrossRef] [PubMed]

76. Talal, N.; Garry, R.F.; Schur, P.H.; Alexander, S.; Dauphinee, M.J.; Livas, I.H.; Ballester, A.; Takei, M.; Dang, H. A conserved idiotype and antibodies to retroviral proteins in systemic lupus erythematosus. J. Clin. Investig. 1990, 85, 1866-1871. [CrossRef] [PubMed]

77. Pelton, B.K.; North, M.; Palmer, R.G.; Hylton, W.; Smith-Burchnell, C.; Sinclair, A.L.; Malkovsky, M.; Dalgleish, A.G.; Denman, A.M. A search for retrovirus infection in systemic lupus erythematosus and rheumatoid arthritis. Ann. Rheum. Dis. 1988, 47, 206-209. [CrossRef]

78. Perl, A.; Nagy, G.; Koncz, A.; Gergely, P.; Fernandez, D.; Doherty, E.; Telarico, T.; Bonilla, E.; Phillips, P.E. Molecular mimicry and immunomodulation by the HRES-1 endogenous retrovirus in SLE. Autoimmunity 2009, 41, 287-297. [CrossRef]

79. Montesion, M.; Williams, Z.H.; Subramanian, R.P.; Kuperwasser, C.; Coffin, J.M. Promoter expression of HERV-K (HML-2) provirus-derived sequences is related to LTR sequence variation and polymorphic transcription factor binding sites. Retrovirology 2018, 15, 57. [CrossRef]

80. Zhou, F.; Li, M.; Wei, Y.; Lin, K.; Lu, Y.; Shen, J.; Johanning, G.L.; Wang-Johanning, F. Activation of HERV-K Env protein is essential for tumorigenesis and metastasis of breast cancer cells. Oncotarget 2016, 7, 84093-84117. [CrossRef]

81. Goering, W.; Schmitt, K.; Dostert, M.; Schaal, H.; Deenen, R.; Mayer, J.; Schulz, W.A. Human endogenous retrovirus HERVK(HML-2) activity in prostate cancer is dominated by a few loci. Prostate 2015, 75, 1958-1971. [CrossRef] [PubMed]

82. Kelly, M.; Lihua, S.; Zhe, Z.; Li, S.; Yoselin, P.; Michelle, P.; Sullivan Kathleen, E. Transposable element dysregulation in systemic lupus erythematosus and regulation by histone conformation and Hsp90. Clin. Immunol. 2018, 197, 6-18. [CrossRef] [PubMed]

83. Elbarbary, R.A.; Lucas, B.A.; Maquat, L.E. Retrotransposons as regulators of gene expression. Science 2016, 351, aac7247. [CrossRef] [PubMed]

84. Pullmann, R., Jr.; Bonilla, E.; Phillips, P.E.; Middleton, F.A.; Perl, A. Haplotypes of the HRES-1 endogenous retrovirus are associated with development and disease manifestations of systemic lupus erythematosus. Arthritis Rheum. 2008, 58, 532-540. [CrossRef]

85. Ostertag, E.M.; Kazazian, H.H., Jr. Biology of mammalian L1 retrotransposons. Annu. Rev. Genet. 2001, 35, 501-538. [CrossRef]

86. Brouha, B.; Schustak, J.; Badge, R.M.; Lutz-Prigge, S.; Farley, A.H.; Moran, J.V.; Kazazian, H.H., Jr. Hot L1s account for the bulk of retrotransposition in the human population. Proc. Natl. Acad. Sci. USA 2003, 100, 5280-5285. [CrossRef]

87. Richardson, S.R.; Doucet, A.J.; Kopera, H.C.; Moldovan, J.B.; Garcia-Perez, J.L.; Moran, J.V. The Influence of LINE-1 and SINE Retrotransposons on Mammalian Genomes. Microbiol. Spectr. 2015, 3, MDNA3-0061-2014. [CrossRef]

88. Petri, R.; Brattas, P.L.; Sharma, Y.; Jonsson, M.E.; Pircs, K.; Bengzon, J.; Jakobsson, J. LINE-2 transposable elements are a source of functional human microRNAs and target sites. PLoS Genet. 2019, 15, e1008036. [CrossRef] [PubMed]

89. Feng, Q.; Moran, J.V.; Kazazian, H.H., Jr.; Boeke, J.D. Human L1 retrotransposon encodes a conserved endonuclease required for retrotransposition. Cell 1996, 87, 905-916. [CrossRef]

90. Mathias, S.L.; Scott, A.F.; Kazazian, H.H., Jr.; Boeke, J.D.; Gabriel, A. Reverse transcriptase encoded by a human transposable element. Science 1991, 254, 1808-1810. [CrossRef] 
91. Tighe, P.J.; Stevens, S.E.; Dempsey, S.; Le Deist, F.; Rieux-Laucat, F.; Edgar, J.D. Inactivation of the Fas gene by Alu insertion: Retrotransposition in an intron causing splicing variation and autoimmune lymphoproliferative syndrome. Genes Immun. 2002, 3 (Suppl. 1), S66-S70. [CrossRef]

92. Heinrich, M.J.; Purcell, C.A.; Pruijssers, A.J.; Zhao, Y.; Spurlock, C.F., 3rd; Sriram, S.; Ogden, K.M.; Dermody, T.S.; Scholz, M.B.; Crooke, P.S., 3rd; et al. Endogenous double-stranded Alu RNA elements stimulate IFN-responses in relapsing remitting multiple sclerosis. J. Autoimmun. 2019, 100, 40-51. [CrossRef] [PubMed]

93. Rice, G.I.; Kasher, P.R.; Forte, G.M.; Mannion, N.M.; Greenwood, S.M.; Szynkiewicz, M.; Dickerson, J.E.; Bhaskar, S.S.; Zampini, M.; Briggs, T.A.; et al. Mutations in ADAR1 cause Aicardi-Goutieres syndrome associated with a type I interferon signature. Nat. Genet. 2012, 44, 1243-1248. [CrossRef]

94. Tossberg, J.T.; Heinrich, R.M.; Farley, V.M.; Crooke, P.S., 3rd; Aune, T.M. Adenosine-to-Inosine RNA Editing of Alu DoubleStranded (ds)RNAs Is Markedly Decreased in Multiple Sclerosis and Unedited Alu dsRNAs Are Potent Activators of Proinflammatory Transcriptional Responses. J. Immunol. 2020, 205, 2606-2617. [CrossRef] [PubMed]

95. Shen, C.K.; Maniatis, T. The organization, structure, and in vitro transcription of Alu family RNA polymerase III transcription units in the human alpha-like globin gene cluster: Precipitation of in vitro transcripts by lupus anti-La antibodies. J. Mol. Appl. Genet. 1982, 1, 343-360.

96. Kole, R.; Fresco, L.D.; Keene, J.D.; Cohen, P.L.; Eisenberg, R.A.; Andrews, P.G. Alu RNA-protein complexes formed in vitro react with a novel lupus autoantibody. J. Biol. Chem. 1985, 260, 11781-11786. [CrossRef]

97. Hung, T.; Pratt, G.A.; Sundararaman, B.; Townsend, M.J.; Chaivorapol, C.; Bhangale, T.; Graham, R.R.; Ortmann, W.; Criswell, L.A.; Yeo, G.W.; et al. The Ro60 autoantigen binds endogenous retroelements and regulates inflammatory gene expression. Science 2015, 350, 455-459. [CrossRef] [PubMed]

98. Mavragani, C.P.; Sagalovskiy, I.; Guo, Q.; Nezos, A.; Kapsogeorgou, E.K.; Lu, P.; Liang Zhou, J.; Kirou, K.A.; Seshan, S.V.; Moutsopoulos, H.M.; et al. Expression of Long Interspersed Nuclear Element 1 Retroelements and Induction of Type I Interferon in Patients With Systemic Autoimmune Disease. Arthritis Rheumatol. 2016, 68, 2686-2696. [CrossRef]

99. Richardson, B.C.; Strahler, J.R.; Pivirotto, T.S.; Quddus, J.; Bayliss, G.E.; Gross, L.A.; O’Rourke, K.S.; Powers, D.; Hanash, S.M.; Johnson, M.A. Phenotypic and functional similarities between 5-azacytidine-treated T cells and a T cell subset in patients with active systemic lupus erythematosus. Arthritis Rheum. 1992, 35, 647-662. [CrossRef]

100. Goldstein, N.; Leider, M.; Baer, R.L. Drug eruptions from anticonvulsant drugs. Observations on drug-induced lesions that were fixed and lupus-erythematosus-like, and on cross-reactivity between several drugs involved. Arch. Dermatol. 1963, 87, 612-617. [CrossRef]

101. Zingale, S.B.; Minzer, L.; Rosenberg, B.; Lee, S.L. Drug induced lupus-like syndrome. Clinical and laboratory syndrome similar to systemic lupus erythematosus following antituberculous therapy: Report of a case. Arch. Intern. Med. 1963, 112, 63-66. [CrossRef] [PubMed]

102. Huang, X.; Su, G.; Wang, Z.; Shangguan, S.; Cui, X.; Zhu, J.; Kang, M.; Li, S.; Zhang, T.; Wu, F.; et al. Hypomethylation of long interspersed nucleotide element-1 in peripheral mononuclear cells of juvenile systemic lupus erythematosus patients in China. Int. J. Rheum. Dis. 2014, 17, 280-290. [CrossRef] [PubMed]

103. Everett, M.A.; Olson, R.L. Response of Cutaneous Lupus Erythematosus to Ultraviolet Light. J. Invest. Dermatol. 1965, 44, 133-138. [CrossRef]

104. Bijl, M.; Kallenberg, C.G. Ultraviolet light and cutaneous lupus. Lupus 2006, 15, 724-727. [CrossRef] [PubMed]

105. Del Re, B.; Giorgi, G. Long INterspersed element-1 mobility as a sensor of environmental stresses. Environ. Mol. Mutagen. 2020, 61, 465-493. [CrossRef] [PubMed]

106. Leffers, H.C.B.; Lange, T.; Collins, C.; Ulff-Moller, C.J.; Jacobsen, S. The study of interactions between genome and exposome in the development of systemic lupus erythematosus. Autoimmun. Rev. 2019, 18, 382-392. [CrossRef]

107. Carter, V.; LaCava, J.; Taylor, M.S.; Liang, S.Y.; Mustelin, C.; Ukadike, K.C.; Bengtsson, A.; Lood, C.; Mustelin, T. High Prevalence and Disease Correlation of Autoantibodies Against p40 Encoded by Long Interspersed Nuclear Elements in Systemic Lupus Erythematosus. Arthritis Rheumatol. 2020, 72, 89-99. [CrossRef]

108. Crow, M.K. Reactivity of IgG with the p40 Protein Encoded by the Long Interspersed Nuclear Element 1 Retroelement: Comment on the Article by Carter et al. Arthritis Rheumatol. 2020, 72, 374-376. [CrossRef]

109. Goodier, J.L.; Zhang, L.; Vetter, M.R.; Kazazian, H.H., Jr. LINE-1 ORF1 protein localizes in stress granules with other RNA-binding proteins, including components of RNA interference RNA-induced silencing complex. Mol. Cell. Biol. 2007, 27, 6469-6483. [CrossRef]

110. Taylor, M.S.; LaCava, J.; Mita, P.; Molloy, K.R.; Huang, C.R.; Li, D.; Adney, E.M.; Jiang, H.; Burns, K.H.; Chait, B.T.; et al. Affinity proteomics reveals human host factors implicated in discrete stages of LINE-1 retrotransposition. Cell 2013, 155, 1034-1048. [CrossRef]

111. De Cecco, M.; Ito, T.; Petrashen, A.P.; Elias, A.E.; Skvir, N.J.; Criscione, S.W.; Caligiana, A.; Brocculi, G.; Adney, E.M.; Boeke, J.D.; et al. L1 drives IFN in senescent cells and promotes age-associated inflammation. Nature 2019, 566, 73-78. [CrossRef]

112. Jiao, H.; Wachsmuth, L.; Kumari, S.; Schwarzer, R.; Lin, J.; Eren, R.O.; Fisher, A.; Lane, R.; Young, G.R.; Kassiotis, G.; et al. Z-nucleic-acid sensing triggers ZBP1-dependent necroptosis and inflammation. Nature 2020, 580, 391-395. [CrossRef]

113. Wang, R.; Li, H.; Wu, J.; Cai, Z.Y.; Li, B.; Ni, H.; Qiu, X.; Chen, H.; Liu, W.; Yang, Z.H.; et al. Gut stem cell necroptosis by genome instability triggers bowel inflammation. Nature 2020, 580, 386-390. [CrossRef] 
114. Bengtsson, A.A.; Sturfelt, G.; Truedsson, L.; Blomberg, J.; Alm, G.; Vallin, H.; Ronnblom, L. Activation of type I interferon system in systemic lupus erythematosus correlates with disease activity but not with antiretroviral antibodies. Lupus 2000, 9, 664-671. [CrossRef] [PubMed]

115. Baechler, E.C.; Batliwalla, F.M.; Karypis, G.; Gaffney, P.M.; Ortmann, W.A.; Espe, K.J.; Shark, K.B.; Grande, W.J.; Hughes, K.M.; Kapur, V.; et al. Interferon-inducible gene expression signature in peripheral blood cells of patients with severe lupus. Proc. Natl. Acad. Sci. USA 2003, 100, 2610-2615. [CrossRef] [PubMed]

116. Bennett, L.; Palucka, A.K.; Arce, E.; Cantrell, V.; Borvak, J.; Banchereau, J.; Pascual, V. Interferon and granulopoiesis signatures in systemic lupus erythematosus blood. J. Exp. Med. 2003, 197, 711-723. [CrossRef] [PubMed]

117. Crow, M.K.; Kirou, K.A.; Wohlgemuth, J. Microarray analysis of interferon-regulated genes in SLE. Autoimmunity 2003, 36, 481-490. [CrossRef] [PubMed]

118. Ronnblom, L.; Alm, G.V.; Eloranta, M.L. Type I interferon and lupus. Curr. Opin. Rheumatol. 2009, 21, 471-477. [CrossRef]

119. Zhao, K.; Du, J.; Peng, Y.; Li, P.; Wang, S.; Wang, Y.; Hou, J.; Kang, J.; Zheng, W.; Hua, S.; et al. LINE1 contributes to autoimmunity through both RIG-I- and MDA5-mediated RNA sensing pathways. J. Autoimmun. 2018, 90, 105-115. [CrossRef]

120. Melki, I.; Rose, Y.; Uggenti, C.; Van Eyck, L.; Fremond, M.L.; Kitabayashi, N.; Rice, G.I.; Jenkinson, E.M.; Boulai, A.; Jeremiah, N.; et al. Disease-associated mutations identify a novel region in human STING necessary for the control of type I interferon signaling. J. Allergy Clin. Immunol. 2017, 140, 543-552.e5. [CrossRef]

121. Bodewes, I.L.A.; Huijser, E.; van Helden-Meeuwsen, C.G.; Tas, L.; Huizinga, R.; Dalm, V.; van Hagen, P.M.; Groot, N.; Kamphuis, S.; van Daele, P.L.A.; et al. TBK1: A key regulator and potential treatment target for interferon positive Sjogren's syndrome, systemic lupus erythematosus and systemic sclerosis. J. Autoimmun. 2018, 91, 97-102. [CrossRef]

122. An, J.; Durcan, L.; Karr, R.M.; Briggs, T.A.; Rice, G.I.; Teal, T.H.; Woodward, J.J.; Elkon, K.B. Expression of Cyclic GMP-AMP Synthase in Patients with Systemic Lupus Erythematosus. Arthritis Rheumatol. 2017, 69, 800-807. [CrossRef] [PubMed]

123. Ronnblom, L.; Eloranta, M.L.; Alm, G.V. The type I interferon system in systemic lupus erythematosus. Arthritis Rheum. 2006, 54, 408-420. [CrossRef] [PubMed]

124. Ronnblom, L. The importance of the type I interferon system in autoimmunity. Clin. Exp. Rheumatol. 2016, 34, 21-24. [PubMed]

125. Arbuckle, M.R.; McClain, M.T.; Rubertone, M.V.; Scofield, R.H.; Dennis, G.J.; James, J.A.; Harley, J.B. Development of autoantibodies before the clinical onset of systemic lupus erythematosus. N. Engl. J. Med. 2003, 349, 1526-1533. [CrossRef]

126. Reynier, F.; Verjat, T.; Turrel, F.; Imbert, P.E.; Marotte, H.; Mougin, B.; Miossec, P. Increase in human endogenous retrovirus HERV-K (HML-2) viral load in active rheumatoid arthritis. Scand. J. Immunol. 2009, 70, 295-299. [CrossRef]

127. Talal, N.; Flescher, E.; Dang, H. Are endogenous retroviruses involved in human autoimmune disease? J. Autoimmun. 1992, 5 (Suppl. SA), 61-66. [CrossRef]

128. Barat, C.; Schatz, O.; Le Grice, S.; Darlix, J.L. Analysis of the interactions of HIV1 replication primer tRNA(Lys,3) with nucleocapsid protein and reverse transcriptase. J. Mol. Biol. 1993, 231, 185-190. [CrossRef]

129. Ji, X.; Klarmann, G.J.; Preston, B.D. Effect of human immunodeficiency virus type 1 (HIV-1) nucleocapsid protein on HIV-1 reverse transcriptase activity in vitro. Biochemistry 1996, 35, 132-143. [CrossRef]

130. Ariumi, Y. Guardian of the Human Genome: Host Defense Mechanisms against LINE-1 Retrotransposition. Front. Chem. 2016, 4 , 28. [CrossRef]

131. Yang, F.; Wang, P.J. Multiple LINEs of retrotransposon silencing mechanisms in the mammalian germline. Semin. Cell Dev. Biol. 2016, 59, 118-125. [CrossRef] [PubMed]

132. Tsutsumi, Y. Hypomethylation of the retrotransposon LINE-1 in malignancy. Jpn. J. Clin. Oncol. 2000, 30, 289-290. [CrossRef] [PubMed]

133. Nawrocki, M.J.; Majewski, D.; Puszczewicz, M.; Jagodzinski, P.P. Decreased mRNA expression levels of DNA methyltransferases type 1 and 3A in systemic lupus erythematosus. Rheumatol. Int. 2017, 37, 775-783. [CrossRef] [PubMed]

134. Tunbak, H.; Enriquez-Gasca, R.; Tie, C.H.C.; Gould, P.A.; Mlcochova, P.; Gupta, R.K.; Fernandes, L.; Holt, J.; van der Veen, A.G.; Giampazolias, E.; et al. The HUSH complex is a gatekeeper of type I interferon through epigenetic regulation of LINE-1s. Nat. Commun. 2020, 11, 5387. [CrossRef]

135. Hunter, R.G.; Murakami, G.; Dewell, S.; Seligsohn, M.; Baker, M.E.; Datson, N.A.; McEwen, B.S.; Pfaff, D.W. Acute stress and hippocampal histone $\mathrm{H} 3$ lysine 9 trimethylation, a retrotransposon silencing response. Proc. Natl. Acad. Sci. USA 2012, 109, 17657-17662. [CrossRef]

136. Wang, X.; Jiang, C.; Fu, B.; Zhu, R.; Diao, F.; Xu, N.; Chen, Z.; Tao, W.; Li, C.J. MILI, a PIWI family protein, inhibits melanoma cell migration through methylation of LINE1. Biochem. Biophys. Res. Commun. 2015, 457, 514-519. [CrossRef]

137. Kuramochi-Miyagawa, S.; Watanabe, T.; Gotoh, K.; Totoki, Y.; Toyoda, A.; Ikawa, M.; Asada, N.; Kojima, K.; Yamaguchi, Y.; Ijiri, T.W.; et al. DNA methylation of retrotransposon genes is regulated by Piwi family members MILI and MIWI2 in murine fetal testes. Genes Dev. 2008, 22, 908-917. [CrossRef]

138. Russell, S.J.; Stalker, L.; LaMarre, J. PIWIs, piRNAs and Retrotransposons: Complex battles during reprogramming in gametes and early embryos. Reprod. Domest. Anim. 2017, 52 (Suppl. 4), 28-38. [CrossRef]

139. Imgenberg-Kreuz, J.; Sandling, J.K.; Almlof, J.C.; Nordlund, J.; Signer, L.; Norheim, K.B.; Omdal, R.; Ronnblom, L.; Eloranta, M.L.; Syvanen, A.C.; et al. Genome-wide DNA methylation analysis in multiple tissues in primary Sjogren's syndrome reveals regulatory effects at interferon-induced genes. Ann. Rheum. Dis. 2016, 75, 2029-2036. [CrossRef] 
140. Sukapan, P.; Promnarate, P.; Avihingsanon, Y.; Mutirangura, A.; Hirankarn, N. Types of DNA methylation status of the interspersed repetitive sequences for LINE-1, Alu, HERV-E and HERV-K in the neutrophils from systemic lupus erythematosus patients and healthy controls. J. Hum. Genet. 2014, 59, 178-188. [CrossRef]

141. Mavragani, C.P.; Nezos, A.; Sagalovskiy, I.; Seshan, S.; Kirou, K.A.; Crow, M.K. Defective regulation of L1 endogenous retroelements in primary Sjogren's syndrome and systemic lupus erythematosus: Role of methylating enzymes. J. Autoimmun. 2018, 88, 75-82. [CrossRef]

142. Lee, J.; Kalia, V.; Perera, F.; Herbstman, J.; Li, T.; Nie, J.; Qu, L.R.; Yu, J.; Tang, D. Prenatal airborne polycyclic aromatic hydrocarbon exposure, LINE1 methylation and child development in a Chinese cohort. Environ. Int. 2017, 99, 315-320. [CrossRef]

143. Breton, C.V.; Yao, J.; Millstein, J.; Gao, L.; Siegmund, K.D.; Mack, W.; Whitfield-Maxwell, L.; Lurmann, F.; Hodis, H.; Avol, E.; et al. Prenatal Air Pollution Exposures, DNA Methyl Transferase Genotypes, and Associations with Newborn LINE1 and Alu Methylation and Childhood Blood Pressure and Carotid Intima-Media Thickness in the Children's Health Study. Environ. Health Perspect. 2016, 124, 1905-1912. [CrossRef]

144. Cornacchia, E.; Golbus, J.; Maybaum, J.; Strahler, J.; Hanash, S.; Richardson, B. Hydralazine and procainamide inhibit T cell DNA methylation and induce autoreactivity. J. Immunol. 1988, 140, 2197-2200.

145. Yung, R.L.; Quddus, J.; Chrisp, C.E.; Johnson, K.J.; Richardson, B.C. Mechanism of drug-induced lupus. I. Cloned Th2 cells modified with DNA methylation inhibitors in vitro cause autoimmunity in vivo. J. Immunol. 1995, 154, 3025-3035. [PubMed]

146. Lieberman, M.W.; Beach, L.R.; Palmiter, R.D. Ultraviolet radiation-induced metallothionein-I gene activation is associated with extensive DNA demethylation. Cell 1983, 35, 207-214. [CrossRef]

147. Yang, Y.G.; Lindahl, T.; Barnes, D.E. Trex1 exonuclease degrades ssDNA to prevent chronic checkpoint activation and autoimmune disease. Cell 2007, 131, 873-886. [CrossRef] [PubMed]

148. Pokatayev, V.; Hasin, N.; Chon, H.; Cerritelli, S.M.; Sakhuja, K.; Ward, J.M.; Morris, H.D.; Yan, N.; Crouch, R.J. RNase H2 catalytic core Aicardi-Goutieres syndrome-related mutant invokes cGAS-STING innate immune-sensing pathway in mice. J. Exp. Med. 2016, 213, 329-336. [CrossRef] [PubMed]

149. Thomas, C.A.; Tejwani, L.; Trujillo, C.A.; Negraes, P.D.; Herai, R.H.; Mesci, P.; Macia, A.; Crow, Y.J.; Muotri, A.R. Modeling of TREX1-Dependent Autoimmune Disease using Human Stem Cells Highlights L1 Accumulation as a Source of Neuroinflammation Cell Stem Cell 2017, 21, 319-331.e8. [CrossRef]

150. Lim, Y.W.; Sanz, L.A.; Xu, X.; Hartono, S.R.; Chedin, F. Genome-wide DNA hypomethylation and RNA:DNA hybrid accumulation in Aicardi-Goutieres syndrome. Elife 2015, 4. [CrossRef]

151. Crow, Y.J.; Chase, D.S.; Lowenstein Schmidt, J.; Szynkiewicz, M.; Forte, G.M.; Gornall, H.L.; Oojageer, A.; Anderson, B.; Pizzino, A.; Helman, G.; et al. Characterization of human disease phenotypes associated with mutations in TREX1, RNASEH2A, RNASEH2B, RNASEH2C, SAMHD1, ADAR, and IFIH1. Am. J. Med. Genet. A 2015, 167A, 296-312. [CrossRef] [PubMed]

152. Crow, Y.J.; Manel, N. Aicardi-Goutieres syndrome and the type I interferonopathies. Nat. Rev. Immunol. 2015, 15, 429-440. [CrossRef] [PubMed]

153. Li, P.; Du, J.; Goodier, J.L.; Hou, J.; Kang, J.; Kazazian, H.H., Jr.; Zhao, K.; Yu, X.F. Aicardi-Goutieres syndrome protein TREX1 suppresses L1 and maintains genome integrity through exonuclease-independent ORF1p depletion. Nucleic Acids Res. 2017, 45, 4619-4631. [CrossRef] [PubMed]

154. Rice, G.I.; Meyzer, C.; Bouazza, N.; Hully, M.; Boddaert, N.; Semeraro, M.; Zeef, L.A.H.; Rozenberg, F.; Bondet, V.; Duffy, D.; et al Reverse-Transcriptase Inhibitors in the Aicardi-Goutieres Syndrome. N. Engl. J. Med. 2018, 379, 2275-2277. [CrossRef] [PubMed]

155. Li, X.; Zhang, J.; Jia, R.; Cheng, V.; Xu, X.; Qiao, W.; Guo, F.; Liang, C.; Cen, S. The MOV10 helicase inhibits LINE-1 mobility. J. Biol. Chem. 2013, 288, 21148-21160. [CrossRef]

156. Arjan-Odedra, S.; Swanson, C.M.; Sherer, N.M.; Wolinsky, S.M.; Malim, M.H. Endogenous MOV10 inhibits the retrotransposition of endogenous retroelements but not the replication of exogenous retroviruses. Retrovirology 2012, 9, 53. [CrossRef]

157. Choi, J.; Hwang, S.Y.; Ahn, K. Interplay between RNASEH2 and MOV10 controls LINE-1 retrotransposition. Nucleic Acids Res. 2018, 46, 1912-1926. [CrossRef]

158. Taylor, M.S.; LaCava, J.; Dai, L.; Mita, P.; Burns, K.H.; Rout, M.P.; Boeke, J.D. Characterization of L1-Ribonucleoprotein Particles. Methods Mol. Biol. 2016, 1400, 311-338. [CrossRef]

159. Lian, H.; Wei, J.; Zang, R.; Ye, W.; Yang, Q.; Zhang, X.N.; Chen, Y.D.; Fu, Y.Z.; Hu, M.M.; Lei, C.Q.; et al. ZCCHC3 is a co-sensor of cGAS for dsDNA recognition in innate immune response. Nat. Commun. 2018, 9, 3349. [CrossRef]

160. Lian, H.; Zang, R.; Wei, J.; Ye, W.; Hu, M.M.; Chen, Y.D.; Zhang, X.N.; Guo, Y.; Lei, C.Q.; Yang, Q.; et al. The Zinc-Finger Protein ZCCHC3 Binds RNA and Facilitates Viral RNA Sensing and Activation of the RIG-I-like Receptors. Immunity 2018, 49, 438-448.e5. [CrossRef]

161. Rice, G.I.; Bond, J.; Asipu, A.; Brunette, R.L.; Manfield, I.W.; Carr, I.M.; Fuller, J.C.; Jackson, R.M.; Lamb, T.; Briggs, T.A.; et al. Mutations involved in Aicardi-Goutieres syndrome implicate SAMHD1 as regulator of the innate immune response. Nat. Genet. 2009, 41, 829-832. [CrossRef]

162. Bogerd, H.P.; Wiegand, H.L.; Doehle, B.P.; Lueders, K.K.; Cullen, B.R. APOBEC3A and APOBEC3B are potent inhibitors of LTR-retrotransposon function in human cells. Nucleic Acids Res. 2006, 34, 89-95. [CrossRef] [PubMed]

163. Refsland, E.W.; Harris, R.S. The APOBEC3 family of retroelement restriction factors. Curr. Top. Microbiol. Immunol. 2013, 371, 1-27. [CrossRef] [PubMed] 
164. Mustelin, T.; Lood, C.; Giltiay, N.V. Sources of Pathogenic Nucleic Acids in Systemic Lupus Erythematosus. Front. Immunol. 2019, 10, 1028. [CrossRef]

165. Barrat, F.J.; Meeker, T.; Gregorio, J.; Chan, J.H.; Uematsu, S.; Akira, S.; Chang, B.; Duramad, O.; Coffman, R.L. Nucleic acids of mammalian origin can act as endogenous ligands for Toll-like receptors and may promote systemic lupus erythematosus. J. Exp. Med. 2005, 202, 1131-1139. [CrossRef]

166. Ronnblom, L.; Alm, G.V. A pivotal role for the natural interferon alpha-producing cells (plasmacytoid dendritic cells) in the pathogenesis of lupus. J. Exp. Med. 2001, 194, F59-F63. [CrossRef] [PubMed]

167. Lloyd, W.; Schur, P.H. Immune complexes, complement, and anti-DNA in exacerbations of systemic lupus erythematosus. Medicine 1981, 60, 208-217. [CrossRef]

168. Kalunian, K.C.; Merrill, J.T.; Maciuca, R.; McBride, J.M.; Townsend, M.J.; Wei, X.; Davis, J.C., Jr.; Kennedy, W.P. A Phase II study of the efficacy and safety of rontalizumab (rhuMAb interferon-alpha) in patients with systemic lupus erythematosus (ROSE). Ann. Rheum. Dis. 2016, 75, 196-202. [CrossRef]

169. Khamashta, M.; Merrill, J.T.; Werth, V.P.; Furie, R.; Kalunian, K.; Illei, G.G.; Drappa, J.; Wang, L.; Greth, W.; on behalf of the CD1067 Study Investigators. Sifalimumab, an anti-interferon-alpha monoclonal antibody, in moderate to severe systemic lupus erythematosus: A randomised, double-blind, placebo-controlled study. Ann. Rheum. Dis. 2016, 75, 1909-1916. [CrossRef]

170. Tanaka, Y.; Tummala, R. Anifrolumab, a monoclonal antibody to the type I interferon receptor subunit 1, for the treatment of systemic lupus erythematosus: An overview from clinical trials. Mod. Rheumatol. 2020, 30, 1-12. [CrossRef]

171. Shao, W.H.; Shu, D.H.; Zhen, Y.; Hilliard, B.; Priest, S.O.; Cesaroni, M.; Ting, J.P.; Cohen, P.L. Prion-like Aggregation of Mitochondrial Antiviral Signaling Protein in Lupus Patients Is Associated with Increased Levels of Type I Interferon. Arthritis Rheumatol. 2016, 68, 2697-2707. [CrossRef] [PubMed]

172. Rodero, M.P.; Decalf, J.; Bondet, V.; Hunt, D.; Rice, G.I.; Werneke, S.; McGlasson, S.L.; Alyanakian, M.A.; Bader-Meunier, B.; Barnerias, C.; et al. Detection of interferon alpha protein reveals differential levels and cellular sources in disease. J. Exp. Med. 2017, 214, 1547-1555. [CrossRef] [PubMed]

173. An, J.; Woodward, J.J.; Minie, M.; Sasaki, T.; Elkon, K.B. Novel Anti-Malarial Drug Derivative Inhibited Type I Interferon Production and Autoimmune Inflammation through Inhibition of CGAS-Sting Pathway in Trex1-/- Mouse (abstract 2984). Arthritis Rheumatol. 2016, 68. Available online: https://acrabstracts.org/abstract/novel-anti-malarial-drug-derivative-inhibited-type-iinterferon-production-and-autoimmune-inflammation-through-inhibition-of-cgas-sting-pathway-in-trex1-mouse/ (accessed on 13 February 2021). 